\title{
Assessment of Irrigation Water Quality and Suitability for Irrigation in the Fincha'a Valley Sugar Estate, Nile Basin of Western Ethiopia
}

\author{
Getahun Kitila $^{1^{\star}}$, Heluf Gebrekidan ${ }^{2}$ and Tena Alamrew ${ }^{2}$ \\ ${ }^{1}$ College of Natural and Computational Sciences, Wollega University, Post Box No: 395, Nekemte, Ethiopia \\ ${ }^{2}$ School of Natural Resource and Environmental Sciences, Haramaya University, Post Box No: 138, \\ Dire Dawa, Ethiopia
}

\begin{tabular}{|c|c|}
\hline Abstract & Article Information \\
\hline \multirow{15}{*}{ 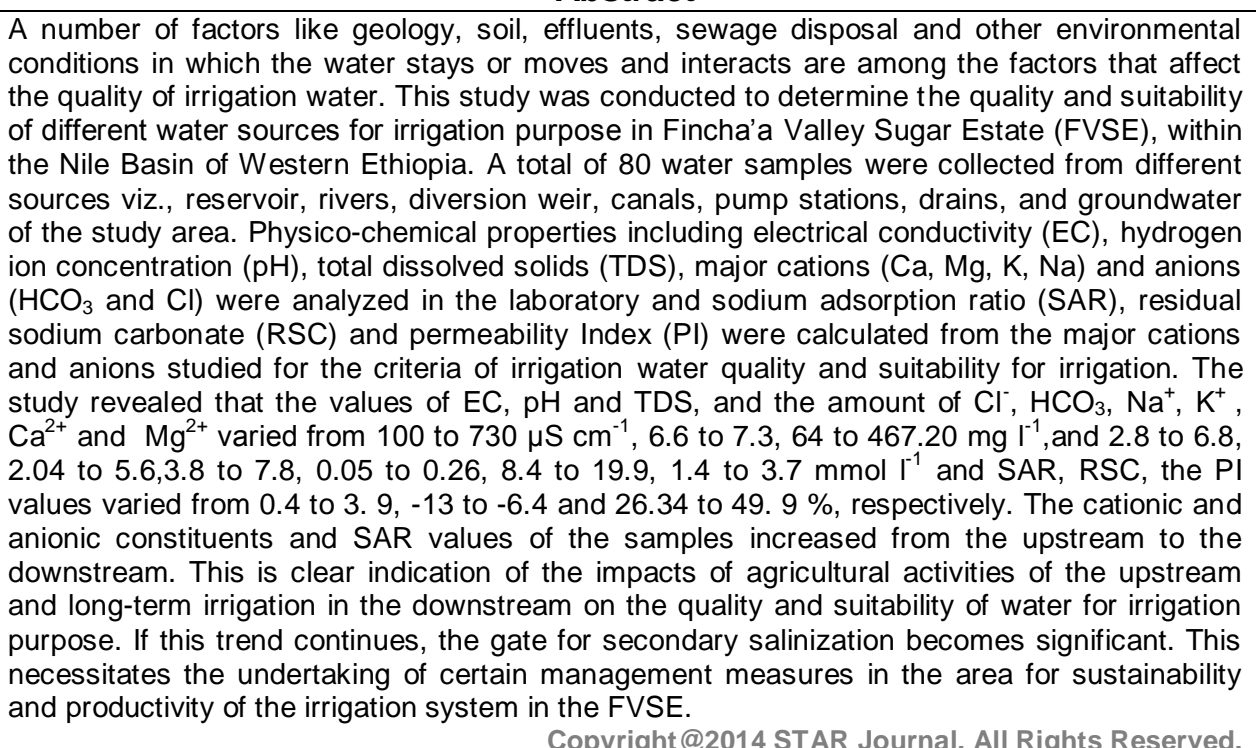 } & rticle History: \\
\hline & Received : 30-12-2013 \\
\hline & Revised : 27-03-2014 \\
\hline & Accepted : 29-03-2014 \\
\hline & Keywords: \\
\hline & fuality \\
\hline & Irrigation \\
\hline & Fincha'a Sugar Estate \\
\hline & Electrical conductivity \\
\hline & Residual sodium carbonate \\
\hline & Salinity \\
\hline & So \\
\hline & \\
\hline & Getahun Kitila \\
\hline & \\
\hline
\end{tabular}

\section{INTRODUCTION}

Irrigated agriculture is dependent on adequate water supply of usable quality. Water quality concerns have often been neglected because good quality water supplies have been plentiful and readily available (Shamsad and Islam, 2005). This situation is now changing in many areas. Intensive use of nearly all good quality supplies means that new irrigation projects, and old projects seeking new or supplemental supplies, must rely on lower quality and less desirable sources (Islam and Shamsad, 2009) and the face of irrigated agriculture is changing with respect to the quantity and quality of water.

Nearly all water contains dissolved salts and trace elements, which results from natural weathering. Drainage water from irrigation fields, industrial waste water and domestic misuse of water also affect the quality of water flowing in our rivers or found in groundwater aquifers. Problems such as high salinity levels of the available water can negatively influence: the crop yield (quantity and quality), the soil's sustainability for irrigation purposes, and the performance of the irrigation system.
Water quality is usually measured by the total dissolved solids (TDS) or the electrical conductivity of the water (EC). A close relationship exists between the TDS of the water and the EC. Since EC is much easier to measure than TDS, it is used as an estimate of the total TDS concentration. In the past, neither irrigators nor agricultural crop advisors in the FSE had to give much consideration to the quality of irrigation water. Supplies of good quality water, well-matched to crop irrigation, were plentiful, generally uncontested, and not necessarily closely monitored or regulated. Water quality concerns have often been neglected because good quality water supplies have been plentiful and readily available (Islam et al., 2004). This situation is now changing in many areas. Intensive use of nearly all good quality supplies means that new irrigation projects, and old projects seeking new or supplemental supplies, must rely on lower quality and less desirable sources (Ragab et al., 2008). Irrigation technology can ensure food security in arid and semi-arid regions. However, its adoption requires efficient systems that ensure sustainable agricultural production (Ndegwa, 2003). 


\section{Getahun et al.,}

Irrigation water quality is related to its effects on soils and crops and its management requirements. High quality crops can be produced only by using high quality irrigation water keeping other inputs optimal. There may be great differences in the quality of water available on a local level depending on whether the source is from surface water bodies (rivers and ponds) or from groundwater aquifers with varying geology and whether the water has been chemically treated or not. The chemical constituents of irrigation water can affect plant growth directly through toxicity or deficiency, or indirectly by altering availability of nutrients (Ayers and Westcot, 1985).

Ragab (2004) studied the effects of irrigation water qualities on chemical properties of soil and observed that there was a progressive and significant increase in soil salinity values as the salinity of irrigation water increases. Accordingly drainage water produced the highest soil salinity levels compared to soil irrigated with canal water. The influence of soils on water quality is very complex and can be ascribed to the processes controlling the exchange of chemicals between the soil and water (Asante et al., 2005). Apart from natural factors influencing water quality, human activities such as domestic and agricultural practices impact negatively on river water quality. It is, therefore, important to carry out water quality assessments for sustainable management of water bodies. A better measure of the sodium ( $\mathrm{Na}$ ) hazard for irrigation is the sodium absorption ratio (SAR) which is used to express the suitability of water for irrigation purposes (Alfred et al., 2011).

Poor quality irrigation water becomes of more concern as the climate changes from humid to arid conditions. Salts are originated from dissolution or weathering of rocks and soil and are carried with the water to wherever it is used (Nata et al., 2008). The quantity and/or composition of the dissolved minerals in natural water depend upon the type of rock or soil with which it has been in contact or through which it has passed and the duration it has been in contact with the rocks and/or soils. Quality of water may vary from place to place, stratum to stratum and season to season. The determination of suitability of water would, therefore, involve a description of the occurrence of the various constituents and their relation to the use to which water would be put.

To determine the quality of irrigation water, we need to identify the characteristics that are important for plant growth, and their acceptable levels of concentrations. Having the water tested by a reputable laboratory is the first step in this process. The water quality data also provides information about geologic history of rocks and quality of the water and its suitability to agriculture. Several authors have reported concerning the quality of water quality and its suitability for irrigation from different parts of the world and the effect of saline water on crop production and soil salinity (e.g. Heluf, 1985; Tena, 2002; Mekuria, 2003; Causapé et al., 2004; Islam et al., 2004; Rao and Devadas, 2005; Vishwanath and Anantha, 2005; Raju, 2006; Singh, 2008; Dhirendra et al., 2009; Megersa et. al., 2009).

Water quality is one of such factors affected by land use change and which is sensitive to changes in landscape patterns in a watershed (Xia et al., 2012; Rachmad and Nobukazu, 2013), and it is generally linked to land use/land cover in catchments (Ahearn et al.,
Sci. Technol. Arts Res. J., Jan-March 2014, 3(1): 64-73

2005). Water quality parameters in various aquatic systems have been closely linked to the proportions or types of land use within a watershed (Lee et al., 2009) and have been influenced by different landscape types (Fu et al., 2005; Fulazzaky, 2010 ). The increasing trend of some water constituents of Fincha'a valley from the upstream to downstream may be due to mentioned factors together with the nature of the basement rock and geological factors.

Since the Ethiopian Government has started to focus its development strategies on the extension of irrigated agriculture especially of large scale projects during the last decade, it has become more important to explore the nexus between irrigation water condition for sustainable agricultural development and potential environmental impacts in the Ethiopian context. However, in Ethiopia, very little information and baseline data are available regarding irrigation, irrigation water quality and its environmental implications. Over-irrigation, excess water seepage from canals during irrigation periods and lack of subsurface drains in the Fincha'a irrigation schemes led to accelerated water logging problems and a rapid rise of the groundwater table. The effects of water logging are manifested in loss of stand, reduced soil aeration, reduced rates of plant growth, reduced yields, and in severe cases, total crop failure.

The Fincha'a Valley sugarcane plantation is mainly dependent on irrigation. However, sustainable utilization of water as a source of water for irrigation requires quality and quantity fitness of the water for this purpose. This paper attempted to addressee these gaps, which is determination of the quality and suitability of the from different sources for irrigation purpose. Therefore, the main center of attention of this paper is mainly to determine the quality and suitability of different water sources in the FSE for irrigation purpose and suggest the optimum solution to increase the productivity of the sugarcane in the FSE within the Blue Nile Basin, Ethiopia.

\section{MATERIALS AND METHODS}

\section{Description of the study area}

Geographically, the Fincha'a Valley Sugar Estate is located in the Fincha'a Valley (FV), Horo Guduru Zone of Oromia Regional State, western highlands of Ethiopia, within the Nile basin, at a distance of $340 \mathrm{~km}$ from Addis Ababa, the capital of Ethiopia and bounded by the Amhara National Regional State in the north, Guduru District in the east, Horro District in the west and Jarte and Amuru District in the south (Figure 1). It lies between $9^{\circ}$ $30^{\prime}$ and $10^{\circ} 00^{\prime} \mathrm{N}$ latitude and $37^{\circ} 15^{\prime}$ and $37^{\circ} 30^{\prime} \mathrm{E}$ longitude. The elevation in the FV varies from 892 to 2520 meters above sea level (m.a.s.l) whereas the study site is within the altitude range between 1350 to 1650 m.a.s.l. Geologically, the area lies within the drainage basin of the Nile basin. The littoral and alluvial deposits of recent sediments underlie the area (Getahun et al., 2013). Fincha'a River originates from the Chomen and Fincha'a swamps on the highlands and divides the scheme into west and east banks and joins the Blue Nile River of Ethiopia. Many streams join the Fincha'a River, the main tributaries being Agamsa, Korke, Fakaree, and Boye from the western side and Sargo-Gobana, Aware, Sombo, and Andode from the eastern side (Worku, 1995).

The thirty two years (1979-2011) climatic data from the FSE Meteorological Station recorded a yearly average 
Getahun et al.,

rainfall of $1315.5 \mathrm{~mm}$ which is characterized by unimodal rainfall pattern. About $80 \%$ of the annual rain falls between May to September. Its mean annual maximum and minimum temperatures are 30.5 and $14.85^{\circ} \mathrm{C}$, respectively (Figure 2). The average annual relative humidity is about $83.8 \%$ (Bayissa, 2007; Awulachew et al., 2007). The FV has alternate wet (during May to October) and dry (during the rest of the months) seasons. Wind speed in the FV is low as the surrounding
Sci. Technol. Arts Res. J., Jan-March 2014, 3(1): 64-73

escarpments hinder wind movement. However, wind speed is high between the months of March to June (Worku, 1995; Ademe, 2001; Amhed, 2007). The soils in the Fincha'a valley are made of alluvia land colluvial materials from the surrounding escarpments (Bezuayehu, 2006). Five major soil types are found in the area of the FVSE of which Luvisols and Vertisols are predominant (Getahun et al., 2013). These soils account for more than $95 \%$ of the cultivated and irrigated lands.

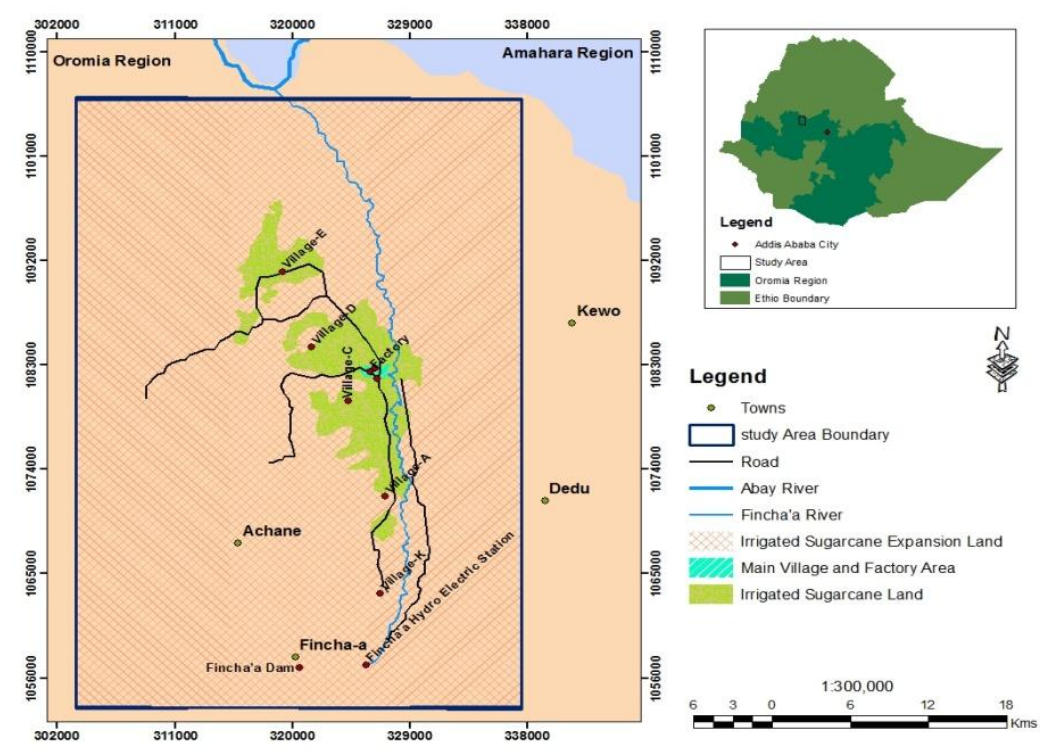

Figure 1: Location map of the study area.

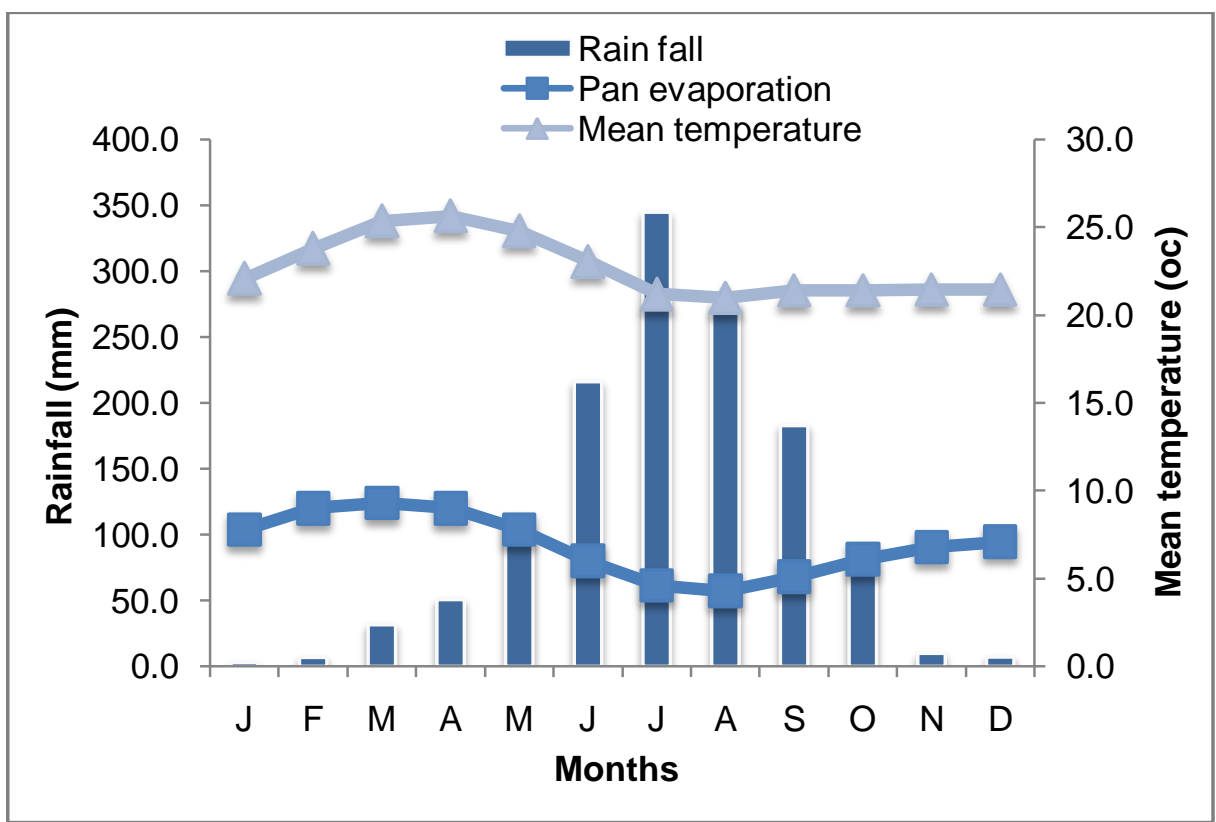

Figure 2: Mean monthly rainfall, maximum and minimum temperatures of the FSE (1979-2011).

\section{Data Sources and Analysis}

Water sampling locations were chosen based on the spatial variations in the water stream and irrigation system (irrigation sources, the distribution canals, the drains, pizometers and from downstream water bodies). The water samples were collected by garb and composite sampling method based on the standard guidelines (UNESCO/WHO/UNEP, 1996 and APHA, 1998) as described in (Masoudi et al., 2006).
The widely accepted threshold values for classifying the suitability of water for irrigation (FAO, 1989) were used. The analysis for the physico-chemical parameters of the samples were carried out following the established analytical methods. Electrical conductivity $\left(E_{\mathrm{w}}\right)$ and $\mathrm{pH}$ $\left(\mathrm{H}_{2} \mathrm{O}\right)$, were determined using electrical conductivity meter provided with automatic temperature compensation and potentiometrically with $\mathrm{pH}$-meter equipped with single probe combined glass-calomed electrode (Greenbergs et al., 1992) respectively. Soluble $\mathrm{Na}^{+}$and $\mathrm{K}^{+}$were determined by flame-photometer after proper calibration 
Getahun et al.,

with combined $\mathrm{Na}-\mathrm{K}$ standard solutions (RTI, 1991) while soluble $\mathrm{Ca}^{+2}$ and $\mathrm{Mg}^{+2}$, were analyzed directly by atomic absorption spectrophotometer (APHA, 1998). Chloride $\left(\mathrm{C1}^{-}\right)$and $\mathrm{HCO}_{3}$ ionswere measured by the argentometric method, by titrating against silver nitrate standard solution with potassium chromate indicator (Greenbergs et al., 1992). Total dissolved solids (TDS) were indicated by weighting the solid residue obtained by evaporation of a measured volume of water samples to dryness (Chopra and Karnwar, 1980). Sulfate $\left(\mathrm{SO}_{4}{ }^{2-}\right)$ was analyzed turbidmetrically as described by Rezwanul et al. (2007) and nitrate content $\left(\mathrm{NO}_{3}{ }^{-}\right)$was determined with spectrophotometric (AOAC, 1990). Since excessive levels of exchangeable $\mathrm{Na}$ can adversely affect soil physicochemical properties, SAR, and residual sodium carbonate (RSC) and the permeability index (PI) of water sources were calculated as described by Mohan and Kumar (2009).

To ensure accuracy analysis was done in three replicates and mean values and correlation were taken into consideration (Appelo and Postma, 2005). The main hazard zones were identified by classifying the values of EC, SAR and RSC according to the limits for suitability to
Sci. Technol. Arts Res. J., Jan-March 2014, 3(1): 64-73

use for agricultural purpose. In this study, the soil characteristics are considered as homogeneous owing to its affinity towards the water. Descriptive statistics were used to analyze the basic characteristics of the data. Analysis of variance (ANOVA) was used to compare variations in water quality under different sources with significance set $(P<0.05)$. Relationships among the considered variables were also tested using Pearson's correlation with statistical significance set $(P<0.05)$.

\section{RESULT AND DISCUSSIONS}

All water samples contain varying amount of different constituents of cations and anions. Among them, the main soluble cations are $\left(\mathrm{Ca}^{2+}, \mathrm{Mg}^{2+}, \mathrm{Na}^{+}\right.$and $\mathrm{K}^{+}$, and anions are $\mathrm{Cl}^{-}, \mathrm{SO}_{4}{ }^{2-} \mathrm{CO}_{3}{ }^{2-}$ and $\mathrm{HCO}_{3}^{-}$. Out of the soluble constituents, $\mathrm{Ca}^{2+}, \mathrm{Mg}^{2+}, \mathrm{Na}^{+}, \mathrm{Cl}^{-}, \mathrm{SO}_{4}{ }^{2-}$ and $\mathrm{HCO}_{3}^{-}$are prime importance in judging the quality of water for irrigation as described by Mahmud et al. 2007. Quddus and Zaman (1996) reported some of these are beneficial and few ions in excess amounts are more or less detrimental for plant growth and soil properties. The chemical composition and quality classification of irrigation water are presented in Tables 1 and 2.

Table 1: Chemical composition of irrigation (surface), underground and drainage waters from Fincha'a Valley areas.

\begin{tabular}{|c|c|c|c|c|c|c|c|c|c|c|c|c|c|c|}
\hline \multirow{2}{*}{$\begin{array}{l}\text { Sampling } \\
\text { site }\end{array}$} & \multirow{2}{*}{ pH } & \multirow{2}{*}{$\begin{array}{c}\text { EC } \\
\left(\mu \mathrm{cm}^{-1}\right)\end{array}$} & \multirow{2}{*}{$\begin{array}{l}\text { TDS } \\
\left(\mathrm{mg} \mathrm{l}^{-1}\right)\end{array}$} & \multicolumn{4}{|c|}{ Cations $\left(\mathrm{mmolc}^{-1}\right)$} & \multirow{2}{*}{ SAR } & \multicolumn{6}{|c|}{ Anions $\left(\mathrm{mmolc}^{-1}\right)$} \\
\hline & & & & $\mathrm{Ca}^{2+}$ & $\mathrm{Mg}^{2+}$ & $\mathrm{Na}^{+}$ & $\mathrm{K}^{+}$ & & $\mathrm{HCO}_{3}^{-}$ & $\mathrm{Cl}^{-}$ & $\mathrm{NO}_{3}^{-}$ & $\mathrm{SO}_{4}^{2-}$ & RSC & $\mathbf{P I}$ \\
\hline & & & \multicolumn{12}{|c|}{ Irrigation water samples } \\
\hline F R & 6.68 & 100.00 & 64.00 & 8.40 & 1.82 & 3.80 & 0.09 & 2.38 & 2.04 & 3.2 & 0.25 & 0.23 & -6.36 & 49.90 \\
\hline DW & 7.12 & 660.00 & 422.40 & 19.85 & 3.65 & 7.02 & 0.08 & 2.05 & 3.17 & 2.8 & 0.27 & 0.18 & -14.20 & 30.77 \\
\hline $\mathrm{KR}$ & 6.60 & 150.00 & 96.00 & 12.07 & 2.20 & 6.51 & 0.26 & 2.43 & 3.60 & 3.2 & 0.28 & 0.28 & -8.40 & 40.06 \\
\hline SR & 6.68 & 130.00 & 83.20 & 18.22 & 1.43 & 5.12 & 0.06 & 1.64 & 2.00 & 3.2 & 0.29 & 0.26 & -16.20 & 26.34 \\
\hline PS & 6.87 & 140.00 & 467.20 & 12.54 & 1.40 & 7.28 & 0.05 & 3.38 & 3.52 & 4.0 & 0.30 & 0.19 & -6.36 & 49.90 \\
\hline$A R$ & 6.88 & 330.00 & 89.60 & 9.40 & 2.24 & 6.25 & 0.09 & 2.99 & 2.04 & 3.6 & 0.32 & 0.25 & -9.63 & 48.30 \\
\hline IC & 6.98 & 350.00 & 224.00 & 14.62 & 2.47 & 4.62 & 0.10 & 1.96 & 3.29 & 3.4 & 0.38 & 0.27 & -11.33 & 34.02 \\
\hline \multirow[t]{2}{*}{$\mathrm{FW}$} & 6.84 & 140.00 & 89.60 & 8.84 & 2.25 & 7.78 & 0.09 & 3.39 & 2.04 & 6.8 & 0.37 & 0.30 & -6.36 & 49.90 \\
\hline & & & \multicolumn{12}{|c|}{ Drainage water samples } \\
\hline \multirow[t]{2}{*}{ DIS } & 7.13 & 650.00 & 350.00 & 17.65 & 2.09 & 7.51 & 0.12 & 3.40 & 4.70 & 3.4 & 0.35 & 0.32 & -12.95 & 42.75 \\
\hline & & & \multicolumn{12}{|c|}{ Groundwater samples } \\
\hline GWP & 7.30 & 730.00 & 211.20 & 14.54 & 2.42 & 7.82 & 0.14 & 3.93 & 5.60 & 6.8 & 0.42 & 0.40 & -9.30 & 38.24 \\
\hline
\end{tabular}

Table 2: Classification of irrigation waters based on its salinity (EC), sodicity (SAR) and residual sodium carbonate (RSC) hazards in the Fincha'a Valley Areas.

\begin{tabular}{|c|c|c|c|c|c|c|c|c|c|}
\hline \multirow[b]{2}{*}{$\begin{array}{l}\text { Sampling } \\
\text { site }\end{array}$} & \multicolumn{3}{|c|}{ Salinity (EC) hazard } & \multicolumn{3}{|c|}{ Sodicity (SAR) hazard } & \multicolumn{3}{|c|}{ Residual N (RSC) hazard } \\
\hline & $\begin{array}{c}\text { Salinity } \\
\text { class }\end{array}$ & $\begin{array}{l}\text { Salinity } \\
\text { hazard }\end{array}$ & $\begin{array}{c}E C \\
\left(\mu \mathrm{cm}^{-1}\right)\end{array}$ & $\begin{array}{l}\text { Sodicity } \\
\text { class }\end{array}$ & $\begin{array}{l}\text { Sodicity } \\
\text { hazard }\end{array}$ & SAR & $\begin{array}{l}\text { RSC } \\
\text { class }\end{array}$ & $\begin{array}{c}\text { RSC } \\
\text { hazard }\end{array}$ & $\begin{array}{c}\mathrm{RSC} \\
\left(\mathrm{mmol} \mathrm{L}^{-1}\right)\end{array}$ \\
\hline \multicolumn{10}{|c|}{ Irrigation water samples } \\
\hline F R & C1 & Low & 100.00 & S1 & Low & 2.38 & 1 & Safe & -6.36 \\
\hline DW & C2 & Medium & 660.00 & S1 & Low & 2.05 & 1 & Safe & -14.20 \\
\hline $\mathrm{KR}$ & C1 & Low & 150.00 & S1 & Low & 2.43 & 1 & Safe & -8.40 \\
\hline SR & C1 & Low & 130.00 & S1 & Low & 1.64 & 1 & Safe & -16.20 \\
\hline PS & C1 & Low & 140.00 & S1 & Low & 3.38 & 1 & Safe & -6.36 \\
\hline AR & $\mathrm{C} 2$ & Medium & 330.00 & S1 & Low & 2.99 & 1 & Safe & -9.63 \\
\hline IC & $\mathrm{C} 2$ & Medium & 350.00 & S1 & Low & 1.96 & 1 & Safe & -11.33 \\
\hline FW & $\mathrm{C} 1$ & Low & 140.00 & S1 & Low & 3.39 & 1 & Safe & -6.36 \\
\hline \multicolumn{10}{|c|}{ Drainage water samples } \\
\hline DIS & $\mathrm{C} 2$ & Medium & 550.00 & S1 & Low & 3.40 & 1 & Safe & -12.95 \\
\hline \multicolumn{10}{|c|}{ Groundwater samples } \\
\hline GWP & $\mathrm{C} 2$ & Medium & 730.00 & S1 & Low & 3.93 & 1 & Safe & -9.30 \\
\hline
\end{tabular}

$\mathrm{FR}=$ Fincha'a Reservoir, DW = Diversion weir, $\mathrm{KR}=$ Korke river, $\mathrm{SR}=$ Settling Reach, $\mathrm{PS}=$ Pump Station,

$\mathrm{AR}=$ Agul River, FW = Factory Waste, DIS = Drains in the Irrigation Sites, GWP = Groundwater in the Pizometers. 


\section{Getahun et al.,}

The EC values of the water samples studied was found to range from $100 \mu \mathrm{S} \mathrm{cm}^{-1}$ for the water sample from the upstream to $730 \mu \mathrm{S} \mathrm{cm}^{-1}$ for the water sample from the downstream (Table 1). Unlike the irrigation (surface) water samples in the drains from the irrigation fields and groundwater from pizometers samples indicated high EC levels, which may be due discharge of untreated wastewater, infiltration and agricultural runoff. The EC value of the drainage water $\left(650 \mu \mathrm{S} \mathrm{cm}^{-1}\right)$, diversion weir $\left(660 \mu \mathrm{S} \mathrm{cm}^{-1}\right)$ and Agul River $\left(140 \mu \mathrm{S} \mathrm{cm}^{-1}\right)$ which are located further downstream of the Valley (in the irrigation scheme) were much higher compared to the values in the upstream area. The increase in the $E C$ value (Fincha'a reservoir) from $100 \mu \mathrm{Sm}^{-1}$ at upstream area of the scheme to $650 \mu \mathrm{S} \mathrm{cm}^{-1}$ (irrigation scheme) at the downstream area again showed the impact of irrigation on the downstream water bodies.

After irrigation, water enters the soil to become soil water which eventually may convert the soil into saline soil. Its composition can change in response to factors such as precipitation of salts, organic matter decomposition and evapotranspiration. However, effects of salt precipitation are generally increasing significantly for most of the water samples since the EC value increased after the entry of water to the irrigation fields (salt concentration of the waters indicated EC values of 100 and $730 \mu \mathrm{S} \mathrm{cm}^{-1}$ for Fincha'a River and ground water. A detailed analysis of the EC values of different water bodies in the adjacent area of the Estate is required to provide a deeper insight in the hydrological system of the irrigation scheme.

The greater EC values $\left(730 \mu \mathrm{S} \mathrm{cm}^{-1}\right)$ for groundwater was the implication of accumulation of salts in the aquifer. The EC $\left(730 \mu \mathrm{S} \mathrm{cm}^{-1}\right)$ is below the critical limit $(1000 \mathrm{dS}$ $\mathrm{m}^{-1}$ ) for osmotic effects to occur and affect crop water availability and permeability. However, management practice is required for sustainability and productivity of the system in the study area. The $\mathrm{pH}$ of the water samples varied from 6.52 to 7.32 indicating slightly acidic to slightly alkaline in reaction with mean value of 6.88 and was within the safe limit for irrigation as it was below the recommended limit of irrigation water for irrigated agriculture (6.0-8.5).

The $\mathrm{pH}$ of irrigation (surface) water (6.60 to 6.84) was comparatively lower than that of groundwater and drains (7.13 to 7.30). The sample from diversion weir (7.12) among the surface water was slightly alkaline in nature and this might be due to the effect of waste disposal and Agrochemicals from the upstream and/or increased value of $\mathrm{Ca}^{2+}, \mathrm{Mg}^{2+}, \mathrm{Na}^{+}$and $\mathrm{HCO}_{3}^{-}$. The increased value of $\mathrm{pH}$ of water in the downstream is the implication of irrigation effects and accumulation of salts. In addition to above parameters $\mathrm{EC}$ and $\mathrm{pH}$, it is also important to consider the TDS in the water, because many of the toxic solid materials may be imbedded in the water which may cause harm to the plants (Sukhdev Kundu, 2012). As EC and TDS values of sample of different water sources are interrelated, both the values are indicative of saline water in absence of non-ionic dissolved constituents (Islam and Shamsad, 2009) and accordingly the water sample from the upstream had less mean TDS values $\left(64 \mathrm{mg} \mathrm{l}^{-1}\right)$ than all the samples from the downstream $\left(467.20 \mathrm{mg} \mathrm{l}^{-1}\right)$.

In terms of 'Degree of restrictions on use', the TDS values $<450,450$ to $467 \mathrm{mg} \mathrm{l}^{-1}$ represent the irrigation
Sci. Technol. Arts Res. J., Jan-March 2014, 3(1): 64-73

water as 'none to slight' respectively (Table 1). So, like $\mathrm{EC}$, the irrigation water of the study area, in term of TDS, is suitable for irrigation purpose. The ground water contains higher amount of various ionic constituents than the surface water. The increase in TDS value down the stream and groundwater similar to EC is the implication of effects of irrigation, use of some chemicals, increased value of ionic constituents and geological nature of the study area. This finding confirmed the results of Sen et al. (2000). High level of TDS in irrigation (surface) water may be due to sedimentation, mining and storm water runoff.

The $\mathrm{HCO}_{3}{ }^{-}$and $\mathrm{Cl}^{-}$contents of the samples of different water sources was found to .range from 2.0 to 3.6 and 2.8 to $6.8 \mathrm{mmolcl}^{-1}$, respectively. The $\mathrm{HCO}_{3}^{-}$and $\mathrm{Cl}^{-}$were dominant in ground water as compared to surface water. The results showed that there was a gradual increase of $\mathrm{Cl}^{-}$concentration and salt content from upstream to downstream indicating the influence of wastes joining at various locations and it was noticed that $\mathrm{Cl}^{-}$concentration is in the increasing trend $\left(4-10 \mathrm{mg} \mathrm{l}^{-1}\right)$. This implies that irrigation at the downstream and wastes joining from the upstream increased the concentration of $\mathrm{Cl}^{-}$and salt content. Nitrate $\left.\mathrm{NO}_{3}{ }^{-}\right)$concentration of the water samples varied from 0.25 to $0.42 \mathrm{mg} \mathrm{L}^{-1}$ (Table 1), mean $\mathrm{NO}_{3}^{-}$ content is higher in the groundwater $\left(0.42 \mathrm{mg} \mathrm{l}^{-1}\right)$ than in the surface (Fincha'a reservoir) water $\left(0.25 \mathrm{mg} \mathrm{l}^{-1}\right)$. Sulphate $\left(\mathrm{SO}_{4}{ }^{2-}\right)$ content of the water samples varied from 0.18 to $0.40 \mathrm{mg} \mathrm{l}^{-1}$.

The $\mathrm{SO}_{4}{ }^{2-}$ content in the water samples were not problematic for irrigating agricultural crops on all soils, where the maximum recommended concentration of $\mathrm{SO}_{4}{ }^{2-}$ was $20 \mathrm{mg} \mathrm{l}^{-1}$ (Ayers and Westcot, 1985). The $\mathrm{NO}_{3}^{-}$ and $\mathrm{SO}_{4}{ }^{2-}$ values of the water sample increased in the downstream of FVSE. The increased value of both $\mathrm{NO}_{3}{ }^{-}$ and $\mathrm{SO}_{4}{ }^{2-}$ is the implication of irrigation effects and use of fertilizers and agrochemicals in the irrigation fields and local community surrounding the FVSE. The result indicated that $\left(\mathrm{CO}_{3}{ }^{2-}\right)$ were below detection in all water samples. Irrigation water that has high sodium $\left(\mathrm{Na}^{+}\right)$ content can bring about a displacement of exchangeable cations (Caand $\mathrm{Mg}$ ) from the clay minerals of the soil, followed by the replacement of the cations by sodium. Sodium-saturated soil peptizes loses their permeability, so that their fertility and suitability for cultivation decrease (Matthess, 1982)

The $\mathrm{Ca}^{2+}$ and $\mathrm{Mg}^{2+}$ contents of the water samples varied from 8.40 to $19.85 \mathrm{mmol} \mathrm{c}-{ }^{1}$ and 1.4 to $2.47 \mathrm{mmolc}$ $\mathrm{I}^{-1}$ respectively (Table 1 ). The $\mathrm{Ca}^{2+}$ and $\mathrm{Mg}^{2+}$ contents were dominant in ground water than in surface water. The $\mathrm{K}^{+}$and $\mathrm{Na}^{+}$contents of the water samples varied from 3.80 to 7.82 and 0.05 to 0.26 mmolc $^{-1}$, respectively.

It is also important to note that large quantities of fertilizers used for agriculture purpose could be the reason for the water sample to have enhanced $\mathrm{K}^{+}$content. In normal case, less quantity of $\mathrm{K}^{+}$is expected in groundwater due to its resistance to weathering conditions. Therefore, the high concentration in the groundwater indicates excessive agriculture activities prevailing in the area. Concentration of $\mathrm{Na}^{+}$in ground water was high, about $7.82 \mathrm{mmolc} \mathrm{I}^{-1}$. This contributed to greater SAR in ground water and drain water compared to surface water. 


\section{Water quality Classification Based on Salinity (EC) Hazard}

The status of water quality in the Fincha'a Valley had been determined based on the USDA (Richards, 1954) method. It can be observed from the result that the mean concentrations of some water quality parameters were already above the threshold (permissible values). For example, the mean concentration of $\mathrm{C}^{-}$was $6.8 \mathrm{mg} \mathrm{I}^{-1}$ beyond the PV $\left(4.0 \mathrm{mg} \mathrm{l}^{-1}\right)$; the average concentration of TDS was $467.20 \mathrm{mg} \mathrm{l}^{-1}$ beyond the PV $\left(450.0 \mathrm{mg} \mathrm{l}^{-1}\right)$, and the mean concentration of EC was $730 \mu \mathrm{S} \mathrm{cm}-1$ beyond the PV $\left(700 \mu \mathrm{S} \mathrm{cm}^{-1}\right)$.

Irrigation water was classified into various classes based on salt concentration (Table 2) and water suitability for irrigation with respect to salinity hazard (Table 2). Most irrigation waters are found in the range of 100 to $730 \mu \mathrm{S}$ $\mathrm{m}^{-1}$, although values as high as $8000 \mu \mathrm{S} \mathrm{m}^{-1}$ have been used on light textured soils having deep water table without significant harm on soil and plants. Water of low salinity can be used for irrigating most crops on most soils. Based on salinity hazard (Richards, 1954) classification (Table 2), salt concentration of the water samples of FVSE irrigation scheme was classified as low for FR, KR, SR and PS whereas medium for AR, IC, DSs and GW. It was identified that water samples ranged from low (C1) to medium (C2) salinity classes and the water samples from $F R, K R$, SR were classified as low $\left(C_{1}\right)$ while the samples from DW, PS, DS, GW and IC were classified as medium $\left(\mathrm{C}_{2}\right)$ salinity class.

Generally $50 \%$ of the water samples were classified as low salinity hazard whereas $50 \%$ of the water samples were classified as medium salinity hazard. However, after a period of time, these low and medium salt levels progressively increase in the root zone, unless they are removed through leaching and drainage. Islam and Shamsad (2009) reported, salt build-up in the soil profile gives rise to saline soils, in the process referred to as secondary salinization. As the salinity level increases, the water becomes less suitable for salt-sensitive crops and for use on soils of low permeability (eg. vertisols). High salinity water can only be used for salt-tolerant crops with good management on well-drained permeable soils. The increasing trend of the water constituents of the samples from different water sources of FVSE from the upstream to downstream may be due to the effects of irrigation, Agrochemicals, land use/land cover changes, soil quality changes and landscape pattern together with the nature of the basement rock and geological factors.

\section{Water quality Classification Based on Sodicity (SAR) Hazard}

An infiltration problem related to water quality occurs when the normal infiltration rate for the applied water or rainfall is appreciably reduced and water remains on the soil surface too long or infiltrates too slowly to supply the crop with sufficient water to maintain acceptable yields. Although the infiltration rate of water into soil varies widely and can be greatly influenced by the quality of the irrigation water, soil factors such as structure, degree of compaction, organic matter content and chemical makeup can also greatly influence the intake rate. The two most common water quality factors that influence the normal infiltration rate are the salinity of the water and its $\mathrm{Na}^{+}$content relative to the $\mathrm{Ca}^{2+}$ and $\mathrm{Mg}^{2+}$ content. Excess $\mathrm{Na}^{+}$in water also produces the undesirable effects of changing soil properties and reducing soil permeability.
Hence, the assessment of sodium concentration is necessary while considering the suitability of water for irrigation purpose. High salinity water will increase infiltration. Low salinity water or water with high $\mathrm{Na}^{+}$to $\mathrm{Ca}^{2+}$ and $\mathrm{Mg}^{2+}$ ratio will decrease infiltration. Both factors may operate at the same time. The infiltration rate generally increases with increasing salinity and decreases with either decreasing salinity or increasing $\mathrm{Na}^{+}$content relative to $\mathrm{Ca}^{2+}$ and $\mathrm{Mg}^{2+}$ the SAR. Therefore, the two factors, salinity (EC) and sodicity (SAR) must be considered together for a proper evaluation of the ultimate effects on water infiltration rate.

High SAR in any irrigation water implies hazard of sodium (Alkali) replacing $\mathrm{Ca}^{2+}$ and $\mathrm{Mg}^{2+}$ of the soil through cation exchange process, a situation eventually damaging to soil structure, namely permeability which ultimately affects the fertility status of the soil and reduce crop yield. Continued use of water having a high SAR value leads to a breakdown in the physical structure of the soil. Sodium (Na) is adsorbed and can be attached to soil particles. The soil then becomes hard and compact when dry and increasingly impervious to water penetration. The degree to which irrigation water tends to enter into cationexchange reactions in soil can be indicated by SAR. The $\mathrm{Na}^{+}$replacing adsorbed $\mathrm{Ca}^{2+}$ and $\mathrm{Mg}^{2+}$ is a hazard as it causes damage to the soil structure. Soil structure becomes compact and impervious as the $\mathrm{Na}^{+}$in the soil solution exceeds that of $\mathrm{Ca}^{2+}$ and $\mathrm{Mg}^{2+}$. There is tendency of irrigation water to generate excessive levels of dissolved sodium, which adversely affect soil physicochemical properties. The SAR is an important parameter for the determination of the suitability of irrigation water and responsible for the sodicity hazard. Sadashivaiah et al. 2008 classified the water samples based on SAR as low $(<10)$, medium (10-18), high (18-26) and very high (> 26). With regard to sodicity (SAR) hazard.

Accordingly, the water samples from different sources of the irrigation scheme in the FV were classified as low sodicity hazard, with SAR values of 1.64 and 3.93 , respectively (Table 2 ). All the samples from different water sources of the FVSE fell under low sodicity hazards and Sodicity (S1) class and as per salinity classification (Richards, 1954). But the increasing trend of SAR value down the stream is implication of the impacts of irrigation together with land use/land cover change, soil quality, landscape pattern, geological and topographical factors on water quality and suitability for irrigation purpose. In the water samples having high concentration of carbonates, there is tendency for $\mathrm{Ca}^{2+}$ and $\mathrm{Mg}^{2+}$ to precipitate as the water in the soil becomes more concentrated. As a result, the relative proportion of $\mathrm{Na}^{+}$in the water is increased in the form of sodium carbonate as described by Sadashivaiah et al. 2008.

Residual carbonate level less than 1.25 mmolc l$^{-1}$ are considered safe. The Water samples with RSC of 1.25$2.50 \mathrm{mmolc} \mathrm{I}^{-1}$ are within the marginal range and $>2.50$ mmolc l-1 unsafe/high. The use of water having RSC more than $2.5 \mathrm{mmol} \mathrm{I}^{-1}$ leads to salt build up which may hinder the air and water movement by clogging the soil pores and lead to degradation of the physical condition of soil. The RSC (2.5-4) $\mathrm{mmolcl}^{-1}$ can be used effectively with the addition of gypsum. Latha et al. 2002 reported, sodic soils could be used with gypsum addition and green manuaring. The study revealed that the RSC value of the water samples varied from -16.2 and -6.3636 mmolcl$^{-1}$. 
Getahun et al.,

The RSC value of the water samples was in decreasing trends expect the value of the sample from pump station (Table 3 ), this is an indication of low sodium hazard and there is no tendency for calcium and magnesium to precipitate as the water in the soil becomes less concentrated. The negative RSC value (Table 1) is the indication of the water samples of the study area were
Sci. Technol. Arts Res. J., Jan-March 2014, 3(1): 64-73

free from residual sodium carbonate (RSC) impacts and dissolved $\mathrm{Ca}^{2+}$ and $\mathrm{Mg}^{2+}$ were greater than that of residual carbonate contents. The PI values of the samples of different water sources of the FVSE varied from $26.34 \%$ to $49.90 \%$. It was identified (Table 3 ) that all samples fall in class (25-75) and safe to use.

Table 3: Suitability classification of irrigation, underground and drainage waters from Fincha'a Valley areas.

\begin{tabular}{ccccc}
\hline & \multicolumn{3}{c}{ Suitability for irrigation } \\
\cline { 2 - 5 } Water \\
\cline { 2 - 5 } & Salinity (EC) & $\begin{array}{c}\text { Sodicity } \\
\text { (SAR) }\end{array}$ & $\begin{array}{c}\text { Alkalinity } \\
\text { (RSC) }\end{array}$ & $\begin{array}{c}\text { General } \\
\text { category }\end{array}$ \\
\hline FR & Very good & fit & fit & Very suitable \\
DW & Good & fit & fit & Suitable \\
KR & Very good & fit & fit & Very suitable \\
SR & Very good & fit & fit & Very suitable \\
PS & Very good & fit & fit & Very suitable \\
AR & Very good & fit & fit & Suitable \\
IC & Good & fit & fit & Suitable \\
FW & Good & fit & fit & Suitable \\
DIS & Good & fit & fit & Suitable \\
GWP & Good & fit & fit & Suitable \\
\hline
\end{tabular}

This is on the soil-plant-water relationships that affect crop production and management. The quality of the samples of different water sources of the FVSE irrigation scheme was within the increasing (salinity hazards) problem since EC value increased from 100 to $730 \mu \mathrm{S}$ $\mathrm{cm}^{-1}$, from the upstream to downstream. The value of the sample from pizometers was above the maximum allowable $\left(700 \mu \mathrm{S} \mathrm{cm}^{-1}\right)$ value. The irrigation water posing problems in terms of salinity hazard requires proper management. The water sample posing problem toxicity of sodium and chloride that can be manifested at higher SAR concentrations and chloride concentrations (4.0 and 6.8) mmolc $\mathrm{I}^{-1}$,which were higher than the maximum allowed values of 3 and $4 \mathrm{mmolc}^{-1}$, respectively. Similarly, it may cause increasing problems of sodium toxicity when used by crops through sub-surface flow, since it had higher SAR and $\mathrm{Cl}^{-}$, which is greater than maximum allowed value of 3 and 4 mmolc $^{-1}$ for sprinkiler irrigation.

\section{Water Suitability of different water sources for irrigation in the FVSE}

Irrigated agriculture is dependent on an adequate water supply of usable quality and Chemical quality of water is a significant factor to determine the suitability of for irrigation. Just as every water is not suitable for human beings, in the same way, every water is not suitable for plant life. Water containing impurities, which are injurious to plant growth, is not satisfactory for irrigation, and called unsatisfactory water. The data generated for the Suitability classification of the samples of different water sources in the FVSE with respect to the use of water for irrigation purpose based on the salinity, sodicity and alkalinity values is given in the Table 3 . The development and continuation of successful irrigation engross not only the supplying of irrigation water to the land but also the control of salt and alkali in the soil.

The total concentration of soluble salts in irrigation water can be expressed in terms of electrical conductivity for the purpose of diagnosis and classification. In general water having conductivity below750 $\mu \mathrm{S} \mathrm{cm}^{-1}$ is satisfactory for irrigation. Water having conductivity in the range of 750 to $2250 \mu \mathrm{S} \mathrm{cm}^{-1}$ is widely used, and satisfactory crop growth is obtained under good management and favorable drainage system. The result indicated that the samples from (DW, AR, IC, DS and GW) had the EC ( $\mu S$ $\mathrm{cm}^{-1}$ ) values $660,330,350,650$ and 730 , respectively, whereas the samples from (FR, KR, SR, PS and FW) had the values $(100,150,130,140$ and 140), respectively were below 750, indicating increasing salinity hazard and/or decreasing suitability for irrigation purpose. In the sample from ( DW, AR, IC, DS and GW), however, the computed EC value (Table 3 ) suggested the necessity of slight to moderate degree of restriction on use of the water from these different water sources for irrigation purpose. In general, the EC value is increasing from the upstream to downstream in the FVSE. This is the indication of the suitability of water for irrigation purpose is decreasing. The likelihood of salinity hazards is high if the water from these different water sources is considered for irrigation use and needs management practice and favorable drainage system for optimum crop production and sustainability of the irrigation system in the Valley. The calculated SAR value specified the degree to which irrigation water tends to enter into cation exchange reactions in soil. The $\mathrm{Na}^{+}$replacing adsorbed $\mathrm{Ca}^{2+}$ and $\mathrm{Mg}^{2+}$ is a danger as it causes harm to the soil composition and becomes compact and impervious.

The result indicated that the samples from (PS, FW, DS and GW) had the SAR value 3.38, 3.39, 3.40 and 3.93, respectively, whereas the samples from (FR, DW, $\mathrm{KR}$ and SR) the SAR values were $(2.38,2.05,2.43$ and $1.64)$, respectively were below 3 , indicating no sodium toxicity will rise by using the water from these different water sources for irrigation purpose. In the sample from (PS, FW, DS and GW), however, the computed SAR value suggested the necessity of slight to moderate degree of restriction on use of the water from these different water sources for irrigation purpose. Out of water samples, $50 \%$ of the water sample of different water sources in the FVSE fall into C1-S1 and $50 \%$ fall into C2S2 category, showing low to medium salinity hazard and low sodicity hazard.

The concentrations of $\mathrm{Ca}^{2+}, \mathrm{Mg}^{2+}, \mathrm{K}^{+}$and $\mathrm{Na}^{+}$in the samples were suitable for irrigation, which is in agreement with the findings of (Rachmad et al., 2013). But the increment of the constituents down the stream is the 
Getahun et al.,

indication of the effects of irrigation together with land use/land cover changes, landscape pattern, geology and climatic condition of the FVSE on the suitability of water for irrigation purpose. The increment of the constituents down the stream is the implication of the decreasing trend of water suitability for irrigation purpose in the Valley. The likelihood of $\mathrm{Na}$ toxicity hazards is high if the water from these different sources is considered for irrigation use.

In addition to the EC and SAR values, RSC in water also influences the suitability of water for irrigation purpose. The result indicated that the water samples that for all the samples from different sources in the FVSE, the RSC value remained negative and all were free from RSC impact, thus showing that the water samples were either satisfactory or within the safe $(<2.5)$ limit to use for irrigation purpose and considered as 'suitable for irrigation. UNESCO (2005) identified the prolong use of water with high RSC affects the yield of crop. Generally, the quality and suitability of different water sources for irrigation purpose was decreasing downstream. This might be due to the upstream agricultural activities and use of chemicals in the downstream area together with geological, runoff and topographical factors; this accelerates the rate of environmental degradation in the downstream areas.
Sci. Technol. Arts Res. J., Jan-March 2014, 3(1): 64-73

Correlation between the Chemical Constituents of Water in the Fincha'a Valley Sugar Estate

The results of the correlation analysis (Table 4) indicated that $\mathrm{EC}$ was statistically highly significant with TDS, SAR, $\mathrm{Na}^{+}, \mathrm{PI}$ and $\mathrm{HCO}_{3}{ }^{-}(P<0.01)$, respectively. While negatively significant with $\mathrm{Ca}^{2+}$ and $\mathrm{Mg}^{2+}(P<0.05)$. $\mathrm{HCO}_{3}{ }^{-}$was highly and positively correlated with $\mathrm{Ca}^{2+}$ and $\mathrm{Mg}^{2+}(\mathrm{p}<0.01)$ and positively correlated with $\mathrm{Na}^{+}(\mathrm{p}<$ 0.05 ) while had, negative and significant associations with PI $(p<0.01)$. High, positive and significant association was identified between $\mathrm{Ca}^{2+}$ and $\mathrm{Mg}^{2+}(\mathrm{p}<0.01)$ while High, negative and significant associations were identified between $\mathrm{Ca}^{2+}$ and SAR, PI $(P<0.01)$, respectively. $\mathrm{Ca}^{2+}$ and $\mathrm{Mg}^{2+}$ had insignificant negative correlation with $\mathrm{Na}^{+}$and $\mathrm{K}^{+} \quad(P>0.05)$. As it can be seen from the correlation matrix, the effect of $\mathrm{Ca}^{2+}$ on total hardness of water was less strong due to precipitation and irrigation effect. Highly positive and significant correlations were identified between $\mathrm{Na}^{+}$and SAR and $\mathrm{PI}(P<0.01)$, respectively (Table 4). The high positive correlations imply that the water physico-chemical properties are influenced by similar climatic, geological, lithological, hydrological and biotic factors that are likely to influence the quality and source of nutrients in the water while the negative correlations mean that the water physico-chemical

Table 4: Pearson`s Correlation coefficient ( $r$ ) among selected physicochemical Constituents of different sources of water sample in the FVSE.

\begin{tabular}{llllllll}
\hline \multirow{2}{*}{ Parameters } & \multicolumn{2}{l}{ Parameters } & & & & & \\
\cline { 2 - 7 } & $\mathbf{E C}$ & $\mathbf{H C O}_{3}{ }^{-2}$ & $\mathbf{C a}^{+2}$ & $\mathbf{M g}^{+2}$ & $\mathbf{N a}^{+}$ & $\mathbf{S A R}$ & $\mathbf{P I}$ \\
\hline $\mathrm{EC}$ & 1.00 & & & & & & \\
$\mathrm{HCO}_{3}{ }^{-2}$ & $0.287^{* *}$ & 1.00 & & & & & \\
$\mathrm{Ca}^{+2}$ & $-0.30^{*}$ & $0.54^{* *}$ & 1.00 & & & & \\
$\mathrm{Mg}^{+2}$ & $-0.25^{\star}$ & $0.60^{* *}$ & $-0.25^{\star *}$ & 1.00 & & & \\
$\mathrm{Na}^{+}$ & $0.40^{\star *}$ & $0.22^{*}$ & -0.04 & -0.25 & 1.00 & & \\
$\mathrm{SAR}$ & $0.66^{* *}$ & $-0.12^{* *}$ & $-0.59^{\star *}$ & $-0.59^{* *}$ & $0.75^{\star *}$ & 1.00 & \\
$\mathrm{PI}$ & $0.60^{\star *}$ & $-0.29^{* *}$ & $-0.74^{* *}$ & $-0.74^{* *}$ & $0.53^{* *}$ & $0.91^{* *}$ & 1.00 \\
\hline
\end{tabular}

${ }^{*}$ and ${ }^{* *}$ Correlation is significant at 0.05 and 0.01 probability levels respectively.

properties are not influenced by similar climatic, geological, lithological, hydrological, and biotic factors and implies that increment of the first parameter contributes to decrement of the second and vice versa.

\section{CONCLUSIONS}

Most problems associated with irrigation waters occur in the long run. Yet, poor-quality water will weaken turfgrass and make it more sensitive to environmental stress and diseases. A qualitative analysis of water based upon the criteria described in this article can prevent many problems making it possible to plan long-range solutions. Water is one of the most important elements in golf course management and it does require a special treatment. Extreme attention must thus be put on any environmental change, such as excavation and drainage activities, the establishment of a new company in the region, smokestack pollution, farm fertilizer spreading, etc. If any doubts subsist, additional analyses must be performed. This study showed the condition of the FSE facing the effects of irrigation development, which affected the water quality. To evaluate the water quality of semiarid tropical Valley like Fincha'a Valley, it is strongly recommended to use GIS and remote sensing technique periodically for spatial and temporal distribution of the constituents to the detail. Different Physico-chemical properties of different water sources of FV were compared with the national and international water quality standards set for irrigation. The $\mathrm{pH}$ values indicated that the water is slightly acidic to slightly alkaline. The increasing EC values of the samples of different water sources in the FV makes the impact of Agricultural activities on the upstream, irrigation together with land use land cover change, landscape pattern, geology, soil quality change, agricultural runoff on the downstream water bodies clearly visible. Drainage water as well as surface run-off water possibly mixed with agrochemicals affected the water quality of the natural water resources in the adjacent area of the irrigation scheme. A detailed analysis of the EC Values of different water bodies in the adjacent area of the Estate is required to provide a deeper insight in the hydrological system of the irrigation scheme. The observation made during the field visit indicated that the obvious malfunction of the waste water treatment plant of the factory poses a threat to downstream water bodies especially to Agul River and its ecosystem. Further investigations are necessary to investigate into the potential impacts of the factory and the scheme on downstream users. Generally, anthropogenic activities along the Fincha'a River basin and weathering could be the source of major ions in the basin. The water is soft because the total calcium and magnesium value was far below the recommended threshold. On the basis of SAR values, no permeability problem was found to exist in samples. However, the increasing trend of these from the 


\section{Getahun et alo,}

upstream to downstream was the indication of the requirement of good water management and drainage for its quality and suitability. Water quality, regarding the physico-chemical parameters, of the FV can be rated as very good-good for irrigation purposes. However, the increase of the EC, $\mathrm{pH}$, TDS, SAR, $\mathrm{Cl}^{-}, \mathrm{SO}_{4}{ }^{2-}, \mathrm{Ca}^{2+}, \mathrm{Mg}^{2+}$, $\mathrm{K}^{+}$and $\mathrm{Na}^{+}$values measured in the upstream area of the scheme to the downstream area showed the water quality of different water sources in the downstream water bodies was in the decreasing trend. Since this study can help us better understand land use/ land cover status, water quality, and their relationship, land use/ land cover should be well managed and some conservation programs should be taken in order to minimize the potential impacts on water quality.

\section{ACKNOWLEDGMENTS}

The authors gratefully acknowledge the assistance of Ethiopian Sugar Corporation and Fincha'a Valley Sugar Estate Research Station for their logistic support and collaboration during the field and laboratory works of this study. They also acknowledged the Ethiopian Ministry of Water Resources and Energy for their collaboration during the analysis of the soils and water samples. Moreover the School of Natural Resources and Environmental Sciences, Haramaya University especially Ayele Akuma \& Samuel Feyisa are highly acknowledged for their unreserved supports during the study time.

\section{REFERENCES}

Ademe, A. (2001). Summary of Metrological Data (1979 2000), Fincha'a Research Station, Agriculture, Ethiopia. Pp 272.

Ahearn, D.S., Sheibley, R.S., Dahlgren, R.A., Anderson, M., Johnson, J., Tate, K.W. (2005). Land use and land cover influence on water quality in thelast free-flowing river draining the western Sierra Nevada, California. Journal of Hydrology 313: 234-247.

Ahmed, A. (2007). GIS and remote sensing integrated environmental impact assessment of irrigationproject in Fincha'a Valley area, Ethiopia. Catchment and Lake Research.

Alfred, K., Godfred, O., Elikem, K. (2011). Assessment of Surface Water Quality: The Perspective of the Weija Dam in Ghana. International Journal of Chemistry 3: 32-39.

AOAC (1990). Official Methods of Analysis of the Association Analytical chemists. $15^{\text {th }}$ ed. Virginia, USA.

APHA (American Public Health Association), (1998). Standard Methods for the Examination of Water and Waste Water'. $17^{\text {th }}$ ed. Washington, D.C. 200005. pp. 1-30 to $40-175$.

Appelo, C.A.J. and Postma. D. (2005). Geochemistry of ground water and pollution, $2^{\text {nd }}$ ed. Balkema publishers, Leiden, pp: 7-20.

Asante, K., Quarcoopome, T. and Amevenku, F. (2005). Water Quality of the Weija Reservoir after 28 years of Impoundment. West African Journal of Applied Ecology 13:171-180.

Awulachew, S. B., Aster, Y.D., Makonnen, L., Willibald, L., Mekonnen A. and Tena, A. (2007). Water Resources and Irrigation Development in Ethiopia. Colombo, Sri Lanka: International Water Management Institute. Pp78.
Sci. Technol. Arts Res. J., Jan-March 2014, 3(1): 64-73

Ayers, R.S. and Westcot, D.W. (1985). Water Quality for Agriculture, Irrigation and Drainage Paper 29, rev. 1, FAO, United Nations, Rome.

Bayissa Chala. (2007). Assessment of Malaria as a Public Health Problem in Fincha'a Sugar Factory based on Clinical Records and Parasitological Surveys. MSc Thesis. Addis Ababa University, Ethiopia.

Bezuayehu, T. (2006). Environmental impact of a Hydropower Dam in Fincha'aWatershed, Ethiopia: Land Use Changes, Erosion Problems, and Soil and Water Conservation Adoption. Sustainable Sloping Lands and Watershed Management Conference. Wageningen University, Wageningen, The Netherlands.

Causapé, J., Quílez, D. and Aragües, R. (2004). Assessment of irrigation and environmental quality at the hydrological basin level irrigation quality. Agricultural Water Management 70: 195-209.

Chopra, S.L. and Kanwar, J.S. (1980). Analytical Agricultural Chemistry', Kalyan Publishers, New Delhi. pp. 168-307.

Dhirendra, M., Alok, K. and Namita, A. (2009). Assessment of the irrigation water quality of river ganga in Haridwar district. Rasāyan Journal of Chemistry 2(2): 285-292.

FAO. (1989). Water quality for agriculture. FAO, Rome, pp. 163.

Fu, B.J., Zhao, W.W., Chen, L.D., Liu, Z.F., Lu, Y.H. (2005). Eco-hydrological effects of landscape pattern change. Landscape and Ecological Engineering 1: 25-32.

Fulazzaky, M.A. (2010). Water quality evaluation system to assess the status and the suitability of the Citarum river water to different uses. Environmental Monitoring and Assessment 168: 669-684.

Getahun, K., Heluf, G., Tena, A., Megersa, O., Hans, H. (2013). Land use changes induced by irrigation development in the Fincha'a sugar estate, Blue nile basin, Ethiopia. Journal of Biodiversity and Environmental Sciences 3(11): 31-47.

Getahun, K., Heluf, G., Tena, A., Geremew, L. (2013). Identification of groundwater level by using geoelectrical resistivity method at Fincha'a Sugar Estate, Blue Nile Basin, Western Ethiopia. Science Technology and Arts Research Journal 2(3): 114-125.

Greenberg, A.E., Clesceri, L.S. and Eaton, A.D. (1992). Standard Methods for the Examination of Water and Waste water $\left(18^{\text {th }} \mathrm{Ed}\right.$.). American public Health Association, American Water Works Association, Water Pollution Control Federation, Washington DC.

Heluf, G. (1985). Investigation on Salt Affected Soils and Irrigation Water Quality in Melka Sedi-Amibara Plain, Rift Valley Zone of Ethiopia, MSc Thesis, School of Graduate Studies, Addis Ababa University. Ethiopia. Pp 131.

Islam, M.R., Jahiruddin, M. and Islam, S. (2004). Assessment of Arsenic in the water-soil-plant systems in Gangetic Floodplains of Bangladesh'. Asian Journal of Plant Science 3(4): 489-493.

Islam, M. S. and Shamsad, S.Z.K.M. (2009). Assessment of Irrigation Water Quality of Bogra District in Bangladesh. Bangladesh Journal of Agricultural Research 34(4): 597608.

Latha, M.R., Indirani, R. Sheeba, S. and Francis, H.J. (2002). Groundwater quality of Coimbatore district, Tamil Nadu. Journal of Ecobiology 14(3): 217-221. 
Getahun et al.,

Lee, S.W., Hwang, S.J., Lee, S.B., Hwang, H.S., Sung, HC. (2009). Landscape ecological approach to the relationships of land use patterns in watersheds towater quality characteristics. Landscape and Urban Planning 92: 80-89.

Mahmud, R., Inoue, N. and Sen, R. (2007). Assessment of Irrigation Water Quality by Using Principal Component Analysis in an Arsenic Affected Area of Bangladesh. Journal of Soil of the Nature 1(2): 08-17.

Masoudi,M.,Patwardhan, A Mand Gore, S D.(2006). A new m ethodology for producing of risk maps of soil salinity, case study: Payab Basin, Iran. Journal of Applied Sciences and Environmental Management 10(3): 913.

Matthess, G. (1982). The Properties of Groundwater. John Willey and Sons, New York. Pp.406.

Megersa, O., Willibald, L. and Josef, F. (2009). Effect of Lake Basaka expansion on the sustainability of Metahara SE in the Awash River basin, Ethiopia. Water, sanitation and hygiene: sustainable development and multi sectoral approaches. $34^{\text {th }}$ WEDC International Conference, Addis Ababa, Ethiopia.

Mekuria, T. (2003). Small scale irrigation for food security in sub-Saharan Africa. Report and recommendations of a CTA study visit Ethiopia, 20-29 January 2003, CTA Working Document Number 8031. The ACP-EU Technical Centre for Agricultural and Rural Cooperation (CTA), The Netherlands.

Mohan, I. and Kumar, A. (2009). Assessment of the Irrigation Water quality of River Water in Haridwar District. Chemistry Department, Chinmaya College of Sciences, Haridwar, Utarakhand, India.

Nata, T., Asmelash, B. and Bheemalingeswara, K. (2008). Initiatives, Opportunities and Challenges in Shallow Groundwater Utilization: a Case Study from Debrekidane Watershed, Hawzien Woreda, Tigray Region, Northern Ethiopia. Agricultural Engineering International: the CIGRE Journal. X: 22.

Ndegwa, G. M and Kiiru, I. (2003). Investigations on soil and water quality as affected by irrigation in turkana district, Kenya. Journal of Agriculture, Science and Technology 12 (1): 11-31.

Quddus, K.G. and Zaman, M.W. (1996). Irrigation water quality in some selected villages of Meherpur in Bangladesh Journal of Agricultural Sciences 23(1): 51-57.

Rachmad, F. and Nobukazu, N. (2013). Assessment of the relationship between land use land cover and water quality status of the tropical watershed: a case of Batang Merao Watershed, Indonesia. Journal of Biodiversity and Environmental Sciences 3(11): 21-30.

Ragab, A.M. (2004). Influence of irrigation with saline drainage waters on some soil physico-chemical properties of the northern west area of Nile delta. Fayom Journal of Agricultural Research and Development 18(1): 133-142.

Ragab, A.A., Hellal, M. and Abd El-Hady, M.(2008). Water Salinity Impacts on Some Soil Properties and Nutrients Uptake by Wheat Plants in Sandy and Calcareous Soil. Australian Journal of Basic and Applied Sciences 2(2): 225-233.

Raju, N.J. (2006). Hydrogeo chemical parameters for assessment of groundwater quality in the upper
Sci. Technol. Arts Res. J., Jan-March 2014, 3(1): 64-73

Gunjanaeru River basin, Cuddapah District, Andhra Pradesh, India. Environmental Geology 52(6): 1067-1074.

Rao, N.S. and Devadas, D.J. (2005). Quality criteria for ground water use for development on an area. Journal of Applied Geochemistry 7(9): 145-160.

Rezwanul, M., Naoto, I. And Ranjit, S. (2007). Assessment of Irrigation Water Quality by Using Principal Component Analysis in Arsenic Affected Area of Bangladesh. Journal of Soil and Nature 1(2): 08-17.

Richards, L.A. (1954).Diagnosis and improvement of saline and alkali soils. Agricultural Handbook. USDA. No. 60, p. 147.

RTI (Royal Tropical Institute), (1991). Analytical Methods of the Laboratory for Soil, Plant and Water Analysis. Part I: Methods for Soil Analysis. Amsterdam, the Netherlands.

Sadashivaiah, C., Ramakrishnaiah, C.R. and Ranganna, G. (2008). Hydro chemical analysis and evaluation of groundwater quality in Tumkur Taluk, Karnataka State, India. International Journal of Environmental Research and Public Health 5(3): 158-164.

Sen, R., Rahman, M.M. and Zaaman M.W. (2000). Ground water and surface water quality for irrigation in some selected sites of Tongi in Gazipur district; Bangladesh Journal of Agricultural Research 25(40): 593-601.

Shamsad, S.Z.K.M. and M. S. Islam. (2005). Hydrochemical behavior of the water resource of Sathkhira Sadar of southwestern Bangladesh and its impact on environment. Bangladesh Journals of Water Resource Research 20: 43-52.

Singh, A.K., Mondal, G.C., Suresh Kumar, T.B., Singh, B.K. Tewary, A. (2008). Major ion chemistry, weathering processes and water quality assessment in upper catchment of Damodar River basin, India. Environmental Geology 54: 745-758.

Sukhdev, K. (2012). Assessment of Surface Water Quality for Drinking and Irrigation Purposes: A Case Study of Ghaggar River System Surface Waters. Bulletin of Environment, Pharmacology and Life Sciences 1(2):1-6.

Tena, A. (2002). Spatial and Temporal Variability of Awash River Water Salinity and the Contribution of Irrigation Water Management in the Development of Soil Salinization Problem in the Awash Valley of Ethiopia, $\mathrm{PhD}$. Thesis, Institute of Hydraulics and Rural Water Management, Department of Water, Atmosphere and Environment, University of Natural Resources Applied Life Sciences, BOKU Vienna.

UNESCO/WHO/UNEP. (1996). Water quality Assessment a Guide to Use of Biota, Sediments, and water in Environmental monitoring ( $2^{\text {nd }} E d$.)

Vishwanath, G. and Murthy, K.S. (2005). Environmental quality status of Amanikere Tank, Tumkur, Karnataka. Indian Mineralogist 1: 85-88.

Worku, B. (1995). Agro ecological Conditions and Back Ground Information on Fincha'a SugarFactory, Fincha'a research station, Ethiopia. MSc Thesis. Alemaya University, Ethiopia.

Xia, L.L., Liu, R.Z, Zao, Y.W. (2012). Correlation analysis of landscape pattern and water quality in Baiyangdian watershed. Procedia Environmental Sciences 13: 21882196. 